\author{
UDK 581.143.6 \\ DOI: $10.31651 / 2076-5835-2018-1-2020-1-71-78$
}

Sergeeva Larisa

к.б.н. старший науковий співробітник, Інститут фізіології рослин і генетики НАН України Zlenko_lora@ukr.net, ORCID 0000-0002-6963-1252 Bronnikova Larisa інженер 1 категорії Інститут фізіології рослин і генетики НАН України ORCID 0000-0002-3776-6208

\title{
CELL SELECTION WITH BARIUM IONS FOR OBTAINING GENETICALLY MODIFIED TOBACCO
}

Introduction. The salinity is one of the most aggressive environmental factors. It provokes the wide range of pathological changes in the plant tissues. The drastic decrease of $K^{+}$cations in plant cells due to salt toxicity is the main feature of injury. The lands with secondary salinization increase. Fresh water in many regions transforms to the product of deficit even to the public. So the problem of obtaining plant forms with elevated levels of salt tolerance becomes extremely significant. Genetic effects that increased the genotype tolerance abilities are the aims of various investigations. Cell selection with heavy metal ions is the appropriate biotechnology for obtaining plant forms that challenged the salinity. The scientific interest to $\mathrm{Ba}^{2+}$ ions is due to its interaction with $\mathrm{K}^{+}$cations. There was shown that $\mathrm{Ba}^{2+}$ interrupted the $\mathrm{K}^{+}$inward transport

Purpose. The obtaining glycophyte-derived salt tolerant forms (cell lines - regenerants progeny) via cell selection.

Methods. Selective systems with lethal doses of barium ions $\left(\mathrm{Ba}^{2+}\right)$ for obtaining tobacco cell forms tolerant to salt stress are proposed and elaborated. The minimum of $\mathrm{Ba}^{2+}$ doses that eliminate wild type cell population was established as lethal doses. Primary calli cultures were initiated from tobacco leaves on B5 cultural agar medium. Cell suspension was cultivated in liquid B5 medium. Cell suspension (wild type) was placed between two layers of agar selective medium with the addition of lethal doses of barium ions ("plating procedure"). Only Ba-resistant cells survive under such stress pressure. The survived cells formed primary minicolonies. Such colonies are considered to be tobacco $B a-r e s i s t a n t$ cell lines $(B a-R C L)$. Ba-RCL grew at $\mathrm{Ba}^{2+}$ ions presence during 3 passages. Then callus was cut and transferred to fresh media: basal medium (normal conditions) and selective media (stress conditions).

Resistant cell variants were tested under lethal salinity. Salt stress was simulated by the addition of sodium chloride or sodium sulfate. There were established three variants of selective systems: medium with the addition of $\mathrm{Ba}^{2+}$ cations, (stress I); cultural media with the addition of salinity (stress II, III). Genetic basis of combined stress resistance was confirmed via media rotations. The changes were: normal conditions $\rightarrow$ stresses I, II, III; stresses I, II, III $\rightarrow$ normal conditions; stress $I \rightarrow$ stress II or stress III or other way roads. The type of cultural medium and the number of passages were always free. As proliferation marker calli relative fresh mass growth (RFW, $\Delta m$ ) was used.

Regenerants and plants of R1 seed progeny were cultivated in vitro at presence of sea water salts.

Result. Tobacco cel lines with combined resistance to lethal ion and chloride and sulfate stresses were obtained via cell selection with $\mathrm{Ba}^{2+}$ cation. Ba-RCL maintained their viability under any stress pressure. The calli relative fresh mass growth $(R F W, \Delta m)$ was always positive.

Regenerants from selected cell lines and RI seed progeny were cultivated at presence of sea water salts $(2,5 \%)$ in vitro. During such cultivations tested plants formed new roots and leaves. After transfer to control (salt free) medium plants adapted to normal conditions. 
Originality of the investigation and its priority was in the promotion of cell selection with $\mathrm{Ba}^{2+}$ cations for obtaining tobacco variants tolerant to lethal salinity.

Conclusion. Cell selection with heavy metal ions is the perspective approach for obtaining genetically modified plant forms. Barium cation is appropriate agent for selection variants with higher tolerance to salinity. Tobacco is a classic glycophyte. From such initial tissues tobacco plant forms (cell lines $\rightarrow$ regenerants $\rightarrow$ progeny) that survive under lethal salinity were obtained. This approach is suitable for other genotypes.

Key words: Nicotiana tabacum, $\mathrm{Ba}^{2+}$ ions, selection in vitro, cell lines with combined stress resistance, salt tolerant plants

\section{The problem setting}

Among abiotic environmental factors salinity is one of the most aggressive. It provokes the wide range of pathological changes in the plant, which is undergoing its action. The drastic decrease of $\mathrm{K}^{+}$cations in plant cells due to salt toxicity is the main feature of injury. At the same time, the number of affected lands is increasing due to salinization, climate change. Fresh water in many regions transforms to the product of deficit even to the public. So the problem of obtaining plant forms with elevated levels of salt tolerance becomes extremely significant.

Unfortunately, the fundamental problem of stress / stability for many reasons is among the most complex. Therefore, the investigation of salt tolerant genotypes (natural and experimentally obtained) will make important contribution to the understanding of the general principles of plant metabolism, growth and development.

For obtaining plants with higher salt tolerance both traditional and modern biotechnological approaches are using, the cell selection is among them. Like any scientific method the cell selection has its positives and limitations and requires new ideas and modifications. We have proposed and tested methodology for cell selection using lethal doses of heavy metal ions for obtaining variants with increased tolerance to osmotic stresses. Thus, to select salt tolerant variants were used barium cations $\mathrm{Ba}^{2+}[1]$.

$\mathrm{Ba}^{2+}$ cation is the restricted agent involved in scientific experiments. This is due to the specificity of its effect on biological objects: an exceptional toxicity to warm-blooded and its lack of need plants [2].

Barium ions are investigated within the group of divalent cations with various effects. Tu S-I et al. (1989), reported, that the presence of barium cations slightly decreased the initial proton pumping rate $\left(R_{0}\right)$ and slightly increased the membrane $\mathrm{H}^{+}$leakage $(\mathrm{k} 1)$ [3]. The net extent proton translocation at steady state $\left(\delta_{\mathrm{s}}\right)$ was also decreased by $\mathrm{Ba}^{2+}$. At presence of inorganic phosphate $\mathrm{Ba}^{2+}$ stimulates malate-pyruvate and succinate oxidation [4]. The unilateral applying of $\mathrm{Ba}^{2+}$ to the root cap caused strong curvature away from the cation in some corn genotypes [5]. $\mathrm{Ba}^{2+}$ was more effective at $1 \mathrm{mM}$ than $5 \mathrm{mM}$, and maximum curvature was reached after about $2.5 \mathrm{~h}$. Curvature in response to unilateral application of $\mathrm{Ba}^{2+}$ to tips of decamped roots was much weaker than that observed in intact roots.

The scientific interest to $\mathrm{Ba}^{2+}$ ions is due too to its interaction with $\mathrm{K}^{+}$cations. It is known that $\mathrm{K}^{+}$cations are physiologically useful cell compartments. There was shown that $\mathrm{Ba}^{2+}$ interrupted the $\mathrm{K}^{+}$inward transport $[6,7]$. Sometimes at $\mathrm{Ba}^{2+}$ presence there was observed the decline of $\mathrm{Na}^{+}$uptake and $\mathrm{K}^{+}$extrusion. In Suaeda maritima the $\mathrm{Na}+$, absorption path was opened at high concentrations of salinity $(150 \mathrm{mM} \mathrm{NaCl})$. It has been found that it is mediated by channel type AKT1. The presence of $\mathrm{Ba} 2+$ ions decreased absorption of $\mathrm{Na}^{+}$ and $\mathrm{K}^{+}$loss [8]. At the same time the negative action of salinity is expressed in drastic leakage of $\mathrm{K}^{+}[9]$.

We supposed that barium ions peculiarities can increase plant salt tolerance. $\mathrm{Ba}^{2+}$ cations became the agents of selection not mutation factor. 
The aim We propose new idea for obtaining tobacco variants tolerant to salt stress via cell selection with $\mathrm{Ba}^{2+}$ cations.

\section{The research methodology and organization}

Tobacco cell cultures (wild type) were initiated from leaves of aseptic young shoots cultivated in vitro. For calli induction and cultivation the B5 Gamborg nutritional medium with agar addition was used [10]. Those calli were used for future cell selection. Suspension cultures were established by replacement calli cultures to liquid shake medium of the same contents for clusters disaggregation. Cell suspensions were grown in $300 \mathrm{ml}$ flasks containing $100 \mathrm{ml}$ per flask. The ratio cell biomass/medium (w/v) was 1:2. The viability level of cell population was estimated according to [11]. The suspension density for plating manipulation was counted: $10 \mathrm{mg}$ of individual cell sediment per $100 \mathrm{ml}$ of liquid medium.

Selective medium for "plating" procedure was elaborated by the addition to B5 medium the lethal for wild type cell cultures doses of barium cations. It was the minimal $\mathrm{Ba}^{2+}$ dose that eliminated control cell cultures.

Cell suspensions $(0,5 \mathrm{ml})$ were plated in Petri dishes between two layers of selective solid media. Dishes were incubated at $25^{\circ} \mathrm{C}$ and monitored for cell growth. Only Ba-resistant cells survive under such stress pressure. The survived cells formed primary minicolonies. Such colonies are considered to be tobacco Ba-resistant cell lines (Ba-RCL). Ba-RCL grew at $\mathrm{Ba}^{2+}$ ions presence during 3 passages. Then callus was cut and transferred to fresh media: basal medium (normal conditions) and selective media (stress conditions).

Three variants of selective systems: medium with the addition of $\mathrm{Ba}^{2+}$ cations, (stress I); cultural media with the addition of salinity (stress II, III) were established. Salt stress was simulated by the addition of sodium chloride or sodium sulfate. Genetic basis of combined stress resistance was confirmed via media rotations. The changes were: normal conditions $\rightarrow$ stresses I, II, III; stresses I, II, III $\rightarrow$ normal conditions; stress I $\rightarrow$ stress II or stress III or other way roads. The type of cultural medium and the number of passages were always free. As a marker of calli proliferation the parameter of relative fresh mass growth (RFW, $\Delta \mathrm{m})$ was used. $\Delta \mathrm{m}$ means: $\left(\mathrm{m}_{\mathrm{f}}-\mathrm{m}_{\mathrm{i}}\right) / \mathrm{m}_{\mathrm{i}}$, where $\mathrm{m}_{\mathrm{i}}$ - initial biomass weight at the start of the passage; $\mathrm{m}_{\mathrm{f}}$ - final biomass weight at the end of the passage [11]. Data of biomass production are statistically analyzed. Data shown are the average of 3 replicates \pm SE.

$\mathrm{Na}^{+}$and $\mathrm{K}^{+}$estimation was determined in fresh tissues by atomic absorption spectrophotometry (Perkin-Elmer 1100B spectrophotometer, Norwalk, CT, USA).

Regenerants were obtained on modified MS medium. Those plants were cultivated in greenhouse. Regenerants and plants of R1 seed progeny were tested under salinity in vitro. Salt stress was simulated by the addition of sea water salts $(2,5 \%)$ to MS medium [12]. Plant salt tolerance was fixed by root and shoot formation de novo.

\section{The results and their discussion}

On selective medium resistant single cells survived and primary colonies were obtained. (The frequency of appearance was $10^{-6}$ ). These colonies later formed Ba-resistant cell lines (Ba-RCL). During 3 - 4 passages calli were cultivated under normal or stress I conditions. The variants viability is regularly controlled. The positive relative fresh mass growth (RFW) indicated the common effectiveness of development.

When cell biomass exceeded $1.0 \mathrm{~g}$ calli cultures were transferred to salinity. It is known that tobacco is a classic glycophyte. So their growth under salinity is a marker of stress tolerance. Table 1 demonstrates the RFW during calli cultivation under various conditions.

Growth indices reflected the cell viability. Conner, A.J. \& Meredith, C.P, (1985), have used this parameter as guaranteed feature of aluminum-resistant cell mutants [11]. In our 
case we obtained salt tolerant mutant cell forms, because they were tested under lethal salinity pressure.

So our cells/cell lines were genetically modified forms. Resistance never did not decrease.

Table 1

Relative fresh mass growth $(\Delta \mathrm{m})$ of tobacco Ba-resistant cell lines (Ba-RCL)

\begin{tabular}{|l|c|c|c|c|}
\hline \multirow{2}{*}{$\begin{array}{c}\text { Resistant } \\
\text { cell line (RCL) }\end{array}$} & $\begin{array}{c}\text { B5, normal } \\
\text { condition }\end{array}$ & B5 $+\mathrm{Ba}^{2+}$ & $\mathrm{B} 5+\mathrm{NaCl}$ & $\mathrm{B} 5+\mathrm{Na}_{2} \mathrm{SO}_{4}$ \\
\cline { 2 - 5 } & $4.59 \pm 0.24$ & $1.67 \pm 0.19$ & $2.25 \pm 0.25$ & $1.58 \pm 0.14$ \\
\hline Ba-RCL № 3 & $5.08 \pm 0.43$ & $2.06 \pm 0.23$ & $2.89 \pm 0.21$ & $3.25 \pm 0.12$ \\
\hline Ba-RCL № 21 & $5.75 \pm 0.12$ & $2.15 \pm 0.03$ & $3.10 \pm 012$ & $2.12 \pm 0.11$ \\
\hline Ba-RCL № 5 & $5.93 \pm 0.44$ & elimination & elimination & Elimination \\
\hline Wild type & \multicolumn{2}{|c|}{} &
\end{tabular}

It is known that the level of the plant stress tolerance can vary considerably during ontogeny. The concept of "salt tolerance", as such, does not properly considered to be absolute. In addition to the classic halophytes a number of genotypes have the increased natural tolerance to salinity, namely, alfalfa, cotton, beets. With this in mind, to confirm the hypothesis of objectivity as a subject of study used a classic glycophyte - the tobacco. Doses of stress-formed agents were always lethal to wild type cultures.

The table demonstrates the viability of Ba-RCL, cultivated under stress conditions. Control cell cultures eliminated at the end of single passage. Compared to normal conditions calli relative fresh mass growth $(\Delta \mathrm{m})$ of resistant cultures decreased under salinity. This event was observed earlier. P. Hasegawa at al. (2000), interpreted this fact as a peculiar feature of salt-adapted cultures. Little fresh weight was due to small cells. Adapted cultures developed osmotic adjustment in such manner [9].

The salt toxicity combined harmful effect of definite ions and disturbance caused by lowered external osmotic potential. So in our experiments $\mathrm{Na}^{+}$ions were added in equal doses. According to $\Delta \mathrm{m}$ meanings we can suggest that Ba-resistant tobacco cell lines demonstrate various reactions to $\mathrm{Cl}^{-}$and $\mathrm{SO}_{4}{ }^{2-}$ anions. Those reactions were the reflection of individual strategy of adaptation because $\Delta \mathrm{m}$ was always positive.

We have described $\mathrm{K}^{+} / \mathrm{Na}^{+}$ratios of Ba-resistant wheat and soybean cell lines. $\mathrm{K}^{+} / \mathrm{Na}^{+}$ ratios were low in calli, cultivated on salt-containing media and the highest under barium ion pressure. At the same time the $\Delta \mathrm{m}$ parameter was positive. We suppose that the salt tolerance of Ba-resistant lines was not connected with $\mathrm{K}^{+}$efflux/accumulation [13].

Table 2 demonstrates $\mathrm{K}^{+} / \mathrm{Na}^{+}$ratios of Ba-resistant tobacco lines. There are essential differences of these parameters and their similarities depended on selective system.

Tobacco Ba-RCL maintained development under any stress pressure. The resistance to the $\mathrm{Ba}^{2+}$ is possibly connected with potassium accumulation. At the same time the salt tolerance is based on another mechanism.

On selective medium with the addition of barium ion tobacco cell lines tolerant to the $\mathrm{Ba}^{2+}$ ion and salinity were obtained. Salt tolerance is realized by ion-depended protective reactions. 
Table 2

$\mathrm{K}^{+} / \mathrm{Na}^{+}$ratios of Ba-resistant cell lines $(\mathrm{Ba}-\mathrm{RCL})$, cultivated on selective media

\begin{tabular}{|l|c|c|c|c|}
\hline \multirow{2}{*}{$\begin{array}{c}\text { Resistant } \\
\text { cell line (RCL) }\end{array}$} & \multicolumn{4}{|c|}{$\mathrm{K}^{+} / \mathrm{Na}^{+}$ratio } \\
\cline { 2 - 5 } & $\begin{array}{c}\text { B5, normal } \\
\text { conditions }\end{array}$ & $\mathrm{B} 5+\mathrm{Ba}^{2+}$ & $\mathrm{B} 5+\mathrm{NaCl}$ & $\mathrm{B} 5+\mathrm{Na}_{2} \mathrm{SO}_{4}$ \\
\hline RCL №3; & 5.50 & 19.05 & 0.12 & 0.11 \\
RCL №21; & 6.31 & 8.37 & 0.11 & 0.10 \\
\hline
\end{tabular}

Tobacco plants were regenerated from some Ba-resistant cell lines Cultures were cultivated in vitro and in greenhouse. Stress tolerant plants maintain growth and development under adverse conditions. Therefore, we declared, that growth and the emergence of new leaves and roots are the markers of plant viability.

In vitro developed regenerants were cut into particles with the same number of leaves and transferred to medium with the addition of sea water salts $(2.5 \%)$. To our opinion this stress agent is the best simulation of ground salinity. The examination of pant salt tolerance in vitro gives the opportunity to detect the times of stress/adaptation reactions.

Regenerants derived from Ba-RCL, formed leaves and root system that is actively consuming components of the culture medium. Plants were kept in stress conditions 35 days. During this time completely tolerant forms used trophic resources. At the same time, this term of cultivation under stress conditions was critical to wild type plants: in the control plants developed pathological lesions. At the end of the passage plants died. Fig. 1 fixed the differences between tolerant and control tobacco plants (7-th day). There were yellow spots of chlorophyll destructions all over the leaves of control plants.

So tolerance to salinity is expressed on plant level. The genetic background of any feature is the inheritable one.

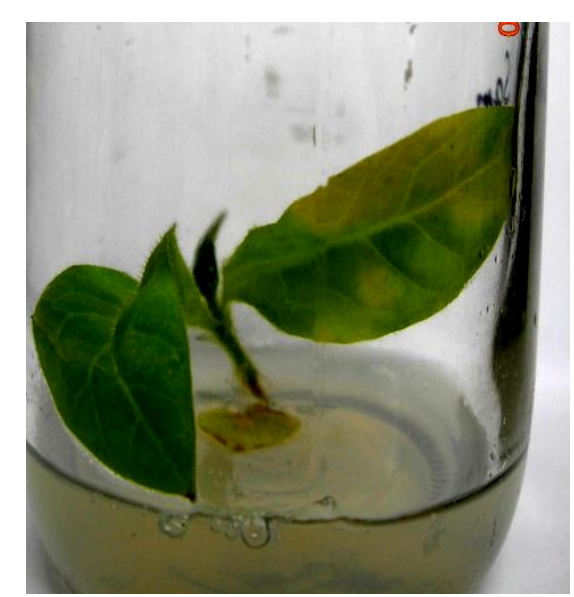

a

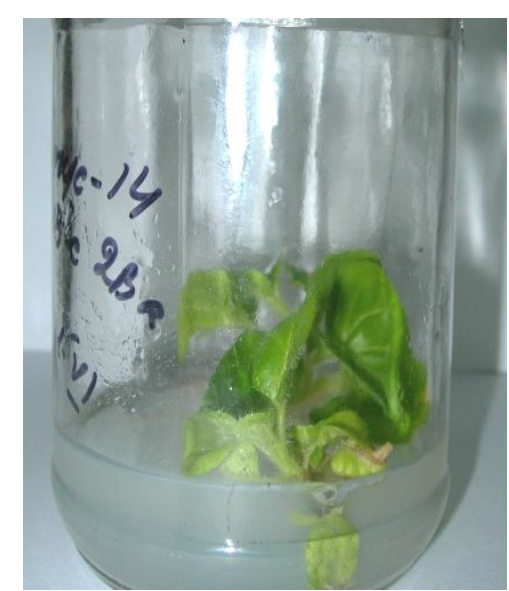

b

Fig. 1. Cultivating tobacco plants under salinity; $a$ - wild type; $b$ - regenerants from Ba-resistant cell line

The R1 seed progeny was obtained. Seeds were exposed under salinity during 21 days. At the end of the third week seeds were transferred to basal MS nutritional medium. Fig. 2, a, shows the differences appeared at 7-th day of cultivation. Salt stress inhibited seeds germination both wild type $(\mathrm{K})$ and new $(\mathrm{R})$ forms. At the same time $\mathrm{K}$ variants eliminated while R variants maintained their viability; (wild type seeds germination cultivated without 
salt exposition - Fig. 2, b). Generally, under normal conditions, there were no differences among tobacco seeds. R1 shoots looked like control ones.

To our opinion the inhibition of R1 seeds that took place was a type of stress adaptive reaction. Under normal conditions R1 shoots activated their metabolism and development.

We use such approach as a mass test of the salt tolerance.

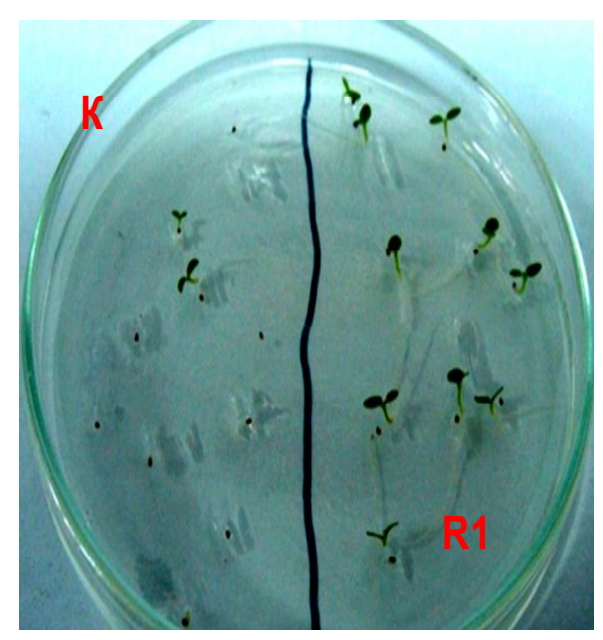

a

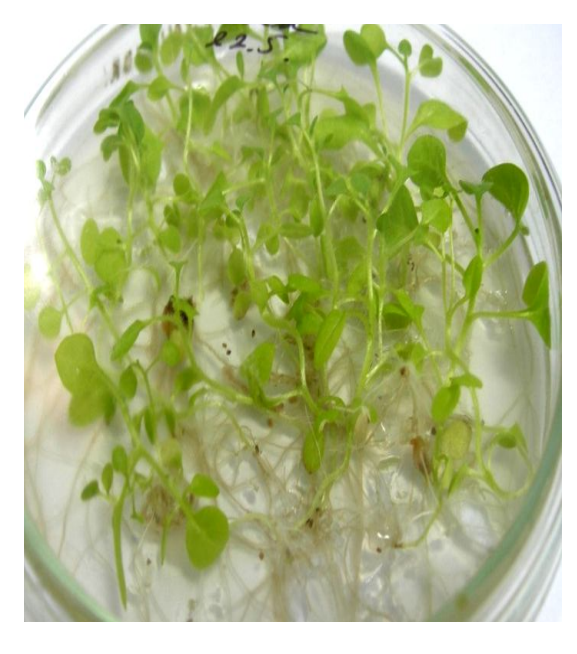

b

Fig. 2. Cultivating tobacco plants on MS medium; a - after salinity exposition; b without stress pressure

The mechanisms which provide salt tolerance to cultured in vitro cells and molecular processes by which cells maintain viability in saline environments are not completely understood. A progress in this area has been made by obtaining and studying glycophytederived cell cultures.

A number of such variants are adaptive forms that achieved the trait in long term tissue cultures. But several passages under normal conditions detect physiological basis of their tolerance. Another type of tolerant cultures does not require prior adaptation to express considerable tolerance to salinity. The basis of such tolerance is connected with their genetic characteristics (changes). The investigation of the experimental chain cell line $\rightarrow$ regenerants $\rightarrow$ seed progeny can guarantee the success.

Tissue culture is a method of creating forms as undifferentiated cells. Those cells can divide indefinitely in vitro and in many cases be induced to regenerate to whole plants. Regeneration of plant from callus cultures of wild type is becoming routine procedure.

At the same time regeneration protocols are objects of permanent modifications. The media rotations are developing for regeneration.

The selective system with $\mathrm{Ba}^{2+}$ is a new approach for obtaining tobacco plants tolerant to salt stress. We suppose the cell selection with heavy metal ions makes contribution to agricultural plant breeding. The knowledge of plant stress tolerance will enrich.

\section{Conclusion}

Cell selection with heavy metal ions is the perspective approach for obtaining genetically modified plant forms. Barium cation is appropriate agent for selection variants with higher tolerance to salinity. Tobacco is a classic glycophyte. From such tissues tobacco plant forms (cell lines $\rightarrow$ regenerants $\rightarrow$ progeny) that survive under lethal salinity were obtained. 


\section{References (in language original)}

1. Сергеева Л.Е. Новая селективная среда с ионами бария - альтернативная система для отбора солеустойчивых клеточных линий. Биотехнология. 2002, №2. С.47-52.

2. Николаев Л.А. Биокатализаторы и их модели М.: Высшая школа. 1968. 196с.

3. Tu S-I Nungesser E. Brauer, D. Characterization of the effect of divalent cations on the coupled activities of the $\mathrm{H}^{+}$-ATPase in tonoplast vesicles. Plant Physiol., 1989. 90, P.1636-1643.

4. Miller R.J., Dumford S.W., Koeppe D.E. Hanson J.B.. Divalent cation stimulation of substrate oxidation by corn mitochondria Ibid, 1970.5. P.649-653.

5. Hasenstein K.H., Evans M.L., Stinemetz C.L., Moore R., Fondrren M., Koon C., Higby M. Smucker, A.J.M. Comparative effectiveness of metal ions in inducing curvature in primary roots of Zea mays. Ibid, 1988. 86. P. 885-889.

6. Rubio F., Nieves-Cordones M., Aleman F. Martinez V. Relative contribution of AtHAK5 and AtHAK 1 to $\mathrm{K}^{+}$uptake in the high affinity range of concentrations. Physiol. Plant. 2008. 134. P.598-608.

7. Fan L.M., Wu W.-H. Yang Y.-Y. Identification and characterization the inward $\mathrm{K}^{+}$channel in the plasma membrane Brassica pollen protoplasts. Plant Cell Physiol. 1999. 40 (8). P.859-865.

8. Wang D.-M., Zhang J.-L. Flowers T.J. Low affinity $\mathrm{Na}^{+}$uptake in the halophyte Suaeda maritima. Plant Physiol., 2007. 145. P.559-571.

9. Hasegawa P.M., Bressan R.A., Zhu J.K. Bohnert H.J. Plant cellular and molecular responses to high salinity. Annu. Rev. Plant Physiol. Plant Mol. Biol., 2000. 51, P. 463-499.

10. Gamborg J.L., Miller R.A. Ojima K. Nutrient requirement of suspension cultures of soybean roots. Exp. Cell Res., 1968. 509. P.151-158.

11. Conner A.J. Meredith C.P. Large scale selection of aluminum-resistant mutants from plant cell culture: expression and inheritance in seedlings. Theor. Appl. Genet., 1985. 71. P. 159-165.

12. Murashige T., Skoog F. A revised medium for rapid growth and bioassays with tobacco tissue culture. Physiol. Plant. 1962. 15. P. 473-497.

13. Sergeeva L.E., Mykhalska S.I. Cell selection with heavy metal ions for obtaining salt tolerant plant cell cultures (2019) Физиол. растений и генетика. (2019. т. 51, №.4, С.315-323. doi.10.15407/frg2019.04.315

\section{References}

1. Sergeeva, L.E. (2002) New selective medium with barium ions is alternative system for obtaining salt resistant cell lines. Biotehnologia [Biotechnology], 2. P.47-52. (in Russ).

2. Nikolaev, L.A. (1968) Biocatalic agents and their models Higher school. - 196p. (in Russ.)

3. Tu, S-I, Nungesser, E. \& Brauer, D. (1989). Characterization of the effect of divalent cations on the coupled activities of the $\mathrm{H}^{+}$-ATPase in tonoplast vesicles. Plant Physiol., 90, P.1636-1643.

4. Miller, R.J., Dumford, S.W., Koeppe D.E. \& Hanson J.B. (1970). Divalent cation stimulation of substrate oxidation by corn mitochondria Ibid, 45, P.649-653.

5. Hasenstein, K.H., Evans, M.L., Stinemetz, C.L., Moore, R., Fondrren, M., Koon, C., Higby, M. \& Smucker, A.J.M. (1988). Comparative effectiveness of metal ions in inducing curvature in primary roots of Zea mays. Ibid, 86, P. 885-889.

6. Rubio, F., Nieves-Cordones, M., Aleman, F. \& Martinez, V. (2008). Relative contribution of AtHAK5 and AtHAK1 to $\mathrm{K}^{+}$uptake in the high affinity range of concentrations. Physiol. Plant., 134, P.598-608.

7. Fan, L.M., Wu, W.-H. \& Yang, Y.-Y. (1999). Identification and characterization the inward $\mathrm{K}^{+}$ channel in the plasma membrane Brassica pollen protoplasts. Plant Cell Physiol., 40 (8), P.859-865.

8. Wang, D.-M., Zhang, J.-L. \& Flowers, T.J. (2007). Low affinity $\mathrm{Na}^{+}$uptake in the halophyte Suaeda maritima. Plant Physiol., 145, P.559-571.

9. Hasegawa, P.M., Bressan, R.A., Zhu, J.K. \& Bohnert, H.J. (2000). Plant cellular and molecular responses to high salinity. Annu. Rev. Plant Physiol. Plant Mol. Biol., 51, P. 463-499.

10. Gamborg, J.L., Miller, R.A. \& Ojima K. (1968). Nutrient requirement of suspension cultures of soybean roots. Exp. Cell Res., 509, P.151-158.

11. Conner, A.J. \& Meredith, C.P, (1985) Large scale selection of aluminum-resistant mutants from plant cell culture: expression and inheritance in seedlings. Theor. Appl. Genet., 71, P. 159-165.

12. Murashige, T., Skoog, F., (1962) A revised medium for rapid growth and bioassays with tobacco tissue culture Physiol. Plant. 15. P. 473-497.

13. Sergeeva, L.E., Mykhalska, S.I. (2019) Cell selection with heavy metal ions for obtaining salt tolerant plant cell culture Fiziologia rastenii $i$ genttika [Plant physiol. and genetics] т.51, №4, P. 315-323 . doi.10.15407/frg2019.04.315 


\section{Сергєєва Л.С., Броннікова Л.І. Клітинна селекція з іонами барію для отримання генетично зміненого тютюну}

Проблематика. Засолення є одним із агресивніших факторів довкілля. Воно здатне спричиняти широкий спектр патологічних змін у тканинах рослин. Різке зниження катіонів $K^{+}$ в клітинах, викликане засоленням, є головною ознакою ушкодження. Зростають площі із вторинним засоленням. Прісна вода у багатьох регіонах перетворюється на дефіцит навіть для людських мас. Отже проблема отримання форм рослин із підвищеним рівнем солестійкості стає надзвичайно актуальною. Генетичні зміни, котрі збільшують стійкість генотипу є головною метою різних досліджень. Клітинна селекиія з іонами важких металів $\epsilon$ перспективною біологічною технологією для отримання форм рослин, здатних протистояти засоленню. Науковий інтерес до іону барію обумовлений його взаємовідносинами із катіонами калію, а саме його здатністю втручатись у прочеси переміщення иього фізіологічно необхідного іону.

Мета. Отримання похідних від глікофітів солестійких форм рослин (клітинна лінія регенерант - потомство) методом клітинної селекції

Методи. Для отримання форм тютюну запропоновано та створено селективну систему із іонами барію $\left(\mathrm{Ba}^{2+}\right)$ у концентраціях, летальних для клітинних культур дикого типу. Летальними вважили найменші конщентрачіï, які призводили до еліміначї̈ культур дикого типу. Первинний калюс ініціювали із листків тютюну на агаризованому середовищі В5. Суспензійну культуру культивували на рідкому середовищі В5. Клітинну культуру дикого типу піддавали прочедурі “плейтингу”, яка передбачає рівномірне розподілення суспензії між двома шарами селективного середовища з іонами $\mathrm{Ba}^{2+}$. Тільки Ва-стійкі клітини виживали за такого стресового навантаження. Живі клітини формували первинні мікроколонії, Такі колонії утворювали Ва-стійкі клітинні лінії (Ва-СКЛ) тютюну. Ва-СКЛ росли у присутності іонів $\mathrm{Ba}^{2+}$ не менше 3 пасажів. У подальшому калюс ділили та перемімували на свіжі середовища, а саме: базальне середовище (нормальні умови) i селективні середовища (стресові умови). Формували два різновиди стресу: середовище із іонами $\mathrm{Ba}^{2+}$ (стрес I) $і$ середовища із солями (стреси II, III). Летальне засолення створювали додаванням хлориду натрію та сульфату натрію. Для підтвердження генетичної основи стійкості використовували ротачію умов культивування, а саме: нормальні умови $\rightarrow$ стреси I, II, III; стреси I, II, III $\rightarrow$ нормальні умови; стрес I $\rightarrow$ стреси II, III тощо. Ротація завжди була довільна. Як показник життєздатності вимірювали відносний приріст сирої біомаси (ВПМ, Аm). Регенеранти та рослини RI насіннєвого покоління культивували у присутності летальних доз солей морської води.

Результати. На селективному середовищі з іонами барію отримано клітинні лінії тютюну,які характеризувались комплексною стійкістю до іону селекиії, а також до летальних сульфатного та хлоридного засолень. Із стійких клітинних ліній регенеровані рослини та отримано Rl насіннєве покоління. Рослини культивували in vitro y присутності 2,5\% солей морської води. В процесі культивування рослини укорінювались і формували нові листки. Після перенесення на безсольове середовище рослини адаптувались до нормальних умов.

Оригінальність та пріоритетність дослідження полягала у створенні селективної системи з іонами $\mathrm{Ba}^{2+}$ та ї̈ застосуванні у клітинній селекиї для виділення форм тютюну, стійких до летального засолення.

Висновки. Клітинна селекиія з іонами важких металів є перспективним підходом виділення генетично змінених форм рослин. Катіон барію є придатним чинником для селекиіі варіантів із підвищеним рівнем солестійкості. Тютюн - ие класичний глікофіт. Із таких тканин отримано форми тютюну (клітинні лінії $\rightarrow$ регенеранти $\rightarrow$ насіннєве потомство), які витримують летальне засолення. Метод може бути поширений на інші генотипи.

Ключові слова: Nicotiana tabacum, іони $\mathrm{Ba}^{2+}$, селекція in vitro, клітинні лінії із комплексною стійкістю, солестійкі рослини

Одержано редакцією

Прийнято до публікації
15.01 .2020

11.06 .2020 